\title{
Relationship of Low Serum Selenium to Anemia among Primary School Children Living in Rural Vietnam
}

\author{
Nguyen VAN NHIEN ${ }^{1,2}$, Nguyen Cong Khan ${ }^{2}$, Tomoki YABUTANI ${ }^{3}$, Nguyen Xuan NINH $^{2}$, \\ Le Thi Kim CHung $^{1,2}$, Junko MotonAKA ${ }^{3}$ and Yutaka NAKAYA ${ }^{1, *}$ \\ ${ }^{1}$ Department of Nutrition and Metabolism, Graduate School of Nutrition and Bioscience, \\ The University of Tokushima, Tokushima 770-8503, Japan \\ ${ }^{2}$ National Institute of Nutrition, Hanoi, Vietnam \\ ${ }^{3}$ Department of Chemical Science and Technology, Faculty of Engineering, \\ The University of Tokushima, Tokushima 770-8506, Japan
}

(Received March 6, 2008)

\begin{abstract}
Summary A cross-sectional study of 292 primary school children was conducted in rural Vietnam to investigate the relationship among micronutrient deficiencies, and other risk factors for anemia. Serum levels of iron, copper, zinc, selenium and magnesium were determined by inductively coupled plasma mass spectrometry and that of retinol by high performance liquid chromatography. Hemoglobin concentration in whole blood was measured by the cyanmethemoglobin method. The incidence of low serum zinc, selenium, magnesium, and copper in the children was 91.4, 75.6, 59.5, and 8.6\%, respectively. Forty-five percent of the children were anemic and $11.3 \%$ suffered from vitamin A deficiency. A parameter significant associated with anemia was low serum selenium and vice versa (OR 1.85, 95\% CI 1.06-3.24, $p<0.05)$. Other factors associated with anemia were serum retinol $<1.05$ $\mu \mathrm{mol} / \mathrm{L}$ (OR 2.05, 95\% CI 1.25-3.36, $p<0.01$ ), and age in years (OR 1.59, 95\% CI $1.16-$ $2.18, p<0.01)$. The study showed that low selenium is associated with anemia among school children in Vietnam. Interventions are required to gain insight into the potential role of selenium on prevention and control of anemia.
\end{abstract}

Key Words anemia, selenium, vitamin A, Vietnam

Anemia remains a major public health problem in developing countries, including Vietnam $(1,2)$. The consequences of anemia include the cognitive performance, behavior, and physical growth of children, the immune status and morbidity from infections and work performance (1). Epidemiological studies showed that iron deficiency is considered the main cause of anemia $(3,4)$. In addition, many previous reports have shown vitamin A deficiency (VAD) is a risk factor for anemia (4-6). However, few studies have been done to characterize the association of deficiency in trace elements with anemia $(7,8)$.

Trace elements such as selenium, zinc, copper, and magnesium are essential for normal human development and functioning of the body (9). They have been implicated to play important roles in immuno-physiologic functions $(9,10)$. The antioxidation function of selenium in glutathione peroxidase is essential in protecting the biological system from oxidation caused by peroxides. Zinc is required for the structure and activity of more than 200 enzymes from many organs in the human body and has a significant task in nucleic acid metabolism, cell replication, tissue repair and growth $(9,10)$. Superoxide dismutases, which usually contain copper and zinc, act as antioxidants against superox-

*To whom correspondence should be addressed.

E-mail: yutaka-nakaya@nutr.med.tokushima-u.ac.jp ides. Magnesium has been known as an essential cofactor for many enzyme systems. It also plays an important role in neurochemical transmission and peripheral vasodilation (9).

Micronutrient deficiencies are likely to be widely prevalent. Although several studies have documented the status of one or two micronutrients among school children (11-13), little information is available on the extent of multiple micronutrient deficiencies during the period $(11,14)$. Moreover, information about anemia and micronutrient deficiencies in Vietnam is still limited. Therefore, the present study was aimed at investigating the prevalence of anemia, vitamin A deficiency, serum levels of selenium, zinc, copper, magnesium, and also to examine their relationships among school children in Vietnam.

\section{MATERIALS AND METHODS}

Subjects. A cross-sectional study was conducted in November 2004 in Bac Ninh province, a rural province situated $50 \mathrm{~km}$ North of Hanoi, in the Red River Delta in Vietnam. Children aged from 72 to 108 mo were chosen by the cluster random sampling method (15). They were recruited from 10 classrooms of three primary schools. All children were examined by study physicians. Only those who were free from chronic and acute illness and congenital abnormality were included.

Ethics. The study protocol was approved by the 
Institutional Review Board of the National Institute of Nutrition in Hanoi, Vietnam. Written informed consent was obtained from the parents or guardians of each child in the survey. In addition, permission was sought from local school boards after meetings in which the purpose and methods of the study were clearly explained by one of the investigators. Children with a hemoglobin $(\mathrm{Hb})$ concentration lower than $70 \mathrm{~g} / \mathrm{L}$ were referred to the local district health center for treatment.

Nutritional assessment. Weight was recorded to the nearest $0.1 \mathrm{~kg}$, while children were minimally clothed, with an electronic digital scale (SECA). Height of children was measured to the nearest $0.1 \mathrm{~cm}$. Z scores of the indicators weight-for-age, length-for-age, and weight-for-length were calculated with EPI-INFO Version 3.3.2 software (Centers for Disease Control and Prevention, Atlanta, USA) using the National Center for Health Statistics data as a reference (16).

Blood sample collection. Fasting blood samples were collected in the morning between 700 and 1100 at the Commune Health Center. Three milliliters of venous blood were drawn into sterile polypropylene tubes and $20 \mu \mathrm{L}$ of the whole blood were immediately mixed in $5 \mathrm{~mL}$ of Drabkin's solution for assessment of $\mathrm{Hb}$ concentration. All tubes were kept in a dark cool box $\left(0-4^{\circ} \mathrm{C}\right)$ and transported to the Micronutrient Laboratory of the National Institute of Nutrition in Hanoi within $6 \mathrm{~h}$. Sera were separated from cells by centrifugation at $4,000 \times g$ for $10 \mathrm{~min}$ at $4^{\circ} \mathrm{C}$. Aliquots of sera were stored at $-70^{\circ} \mathrm{C}$ until analysis. For determination of trace elements the sera were kept on dry ice and brought to the University of Tokushima, Japan.

Determination of $\mathrm{Hb}$, vitamin $A$ and trace elements. Hemoglobin was determined in whole blood by the cyanmethemoglobin method within $12 \mathrm{~h}$ of sampling using Sigma diagnostic kits (Sigma). Serum retinol was analyzed by using high performance liquid chromatography (HPLC model LC 10ADvp, Shimadzu, Kyoto, Japan) according to the method of the International Vitamin A Consultative Group in a darkened room at the National Institute of Nutrition in Hanoi, Vietnam (17).

Concentrations of elements in serum were determined at The University of Tokushima, Japan by using an inductively coupled plasma mass spectrometer (ICPMS, model 8500, Shimadzu) according to method of Hasegawa et al. (18). Basically, $200 \mu \mathrm{L}$ of serum sample were aliquoted into a teflon tube and covered with a teflon ball. After adding $1.5 \mathrm{~mL}$ of concentrated $\mathrm{HNO}_{3}$ (Wako Pure Chemical Industries, Ltd., Osaka, Japan), the tube was heated on an aluminum-heating block (IWAKI, Asahi Techno Glass, Funabashi, Japan) at $120^{\circ} \mathrm{C}$ for $5 \mathrm{~h}$. The sample was further heated almost to dryness at $200^{\circ} \mathrm{C}$ after removing the teflon ball. Finally, the residue was dissolved with $2 \mathrm{~mL}$ of $0.1 \mathrm{M} \mathrm{HNO}_{3}$, which contained $10 \mathrm{ng} / \mathrm{mL}$ internal standard elements (indium, rhenium, and thallium). The diluted serum solution was used for analysis in the ICP-MS. The multi standard solutions for standardization of calibration curves were prepared from the single element standard solutions $(1,000 \mu \mathrm{g} / \mathrm{mL})$, purchased from Wako Pure Chemical Industries, Ltd. The results were calculated from three runs.

Statistical analysis. All data were analyzed using the SPSS software for Windows, version 11.0 (SPSS, Inc., Chicago, Illinois, USA). A one-sample KolmogorovSmirnov test was used to assess whether the data were normally distributed. When data were not normally distributed, statistical analysis was carried out after log transformation. Anemia was defined as a $\mathrm{Hb}$ level below $115 \mathrm{~g} / \mathrm{L}$ (19). Vitamin A deficiency was defined as a serum retinol level below $0.70 \mu \mathrm{mol} / \mathrm{L}$ (17). The following criteria were used to define the risk of trace element deficiencies: serum selenium $<70 \mu \mathrm{g} / \mathrm{L}$, serum copper $<750 \mu \mathrm{g} / \mathrm{L}$, serum magnesium $<18.0 \mathrm{mg} / \mathrm{L}$ (20), and serum zinc $<650 \mu \mathrm{g} / \mathrm{L}(21)$. Logistic regression analyses were used to find the relation between anemia, serum levels of trace elements, and some parameters of the study subjects. Regression coefficients were converted to odds ratios (OR), and the confidence intervals (CI) for the odds ratios were derived from the standard error estimates of the regression coefficients. Differences in variables between genders were examined by using an independent-samples $t$-test. Statistically significant differences were indicated by $p<0.05$.

\section{RESULTS}

A total of 292 primary school children aged from 72 to $108 \mathrm{mo}$, were included in the study. Of these children, 290 had $\mathrm{Hb}$ values, and 291 had serum retinol and trace elements concentration measured. The mean \pm SD age of the 292 children was $93.3 \pm 9.1$ mo, and they were 140 boys and 152 girls. The mean weight-for-age Z-score (WAZ), height-for-age Z-score (HAZ), and weight-for-height Z-score (WHZ) were $-1.82 \pm 0.65,-1.62 \pm 0.80$, and $-1.15 \pm 0.70$, respectively (Table 1). The prevalence of children with underweight (WAZ $<-2$ ), stunting (HAZ $<-2$ ), and wasting (WHZ<-2) was 39.2\% (114/291), 32.6\% (95/291), and $10.3 \%(30 / 291)$, respectively. There was a significant difference in the prevalence of underweight $(p<0.05)$ and stunting $(p<0.01)$ between two genders, but no significant differences were observed in the prevalence of wasting between the boys and girls.

The mean $\mathrm{Hb}$ concentration in the children was $114.5 \pm 9.9 \mathrm{~g} / \mathrm{L}$. Hb levels among boys $(n=139)$ and girls $(n=151)$ were $114.0 \pm 9.5$ and $114.9 \pm 10.3 \mathrm{~g} / \mathrm{L}$, respectively. From the total study population, $45.2 \%$ (131/290) of the children were found to be anemic but none of these children had severe anemia $(\mathrm{Hb}<70 \mathrm{~g} / \mathrm{L})$. The mean ages of children with and without anemia were $91.2 \pm 10.3$ and $94.9 \pm 7.7 \mathrm{mo}$, respectively $(p<0.001)$. The geometric mean serum retinol concentration of the study subjects was $0.97 \mu \mathrm{mol} / \mathrm{L}$, and the overall prevalence of VAD was $11.3 \%(33 / 291)$. The prevalence of VAD did not differ significantly by gender, age or nutritional status. On the other hand, a large proportion of the children $(52.6 \%)$ had serum retinol in the range of 0.70 to $1.04 \mu \mathrm{mol} / \mathrm{L}$, thus just above the cut-off level for VAD (Table 1). 
Table 1. Anthropometric and hematological indices of primary school children in living in rural Vietnam.

\begin{tabular}{|c|c|c|c|}
\hline Variable & Boys $(n=140)$ & Girls $(n=152)$ & Total $(n=292)$ \\
\hline \multicolumn{4}{|l|}{ Anthropometry } \\
\hline $\operatorname{Age}^{1}(\mathrm{mo})$ & $93.0 \pm 9.2$ & $93.6 \pm 9.1$ & $93.3 \pm 9.1$ \\
\hline Height $(\mathrm{cm})$ & $116.3 \pm 5.6$ & $116.4 \pm 5.7$ & $116.3 \pm 5.6$ \\
\hline Weight (kg) & $18.9 \pm 2.4$ & $18.6 \pm 2.3$ & $18.7 \pm 2.3$ \\
\hline Underweight, $n(\%)$ & $64(45.7)$ & $50(33.1)$ & $114(39.2)$ \\
\hline \multicolumn{4}{|l|}{ Blood analysis } \\
\hline Hemoglobin (g/L) & $114.0 \pm 9.5$ & $114.9 \pm 10.3$ & $114.5 \pm 9.9$ \\
\hline Anemia, $n(\%)$ & $69(49.6)$ & $62(41.1)$ & $131(45.2)$ \\
\hline Serum retinol $(\mu \mathrm{mol} / \mathrm{L})$ & $0.94(0.90 ; 0.99)$ & $0.99(0.94 ; 1.05)$ & $0.97(0.93 ; 1.00)$ \\
\hline Vitamin A deficiency, $n(\%)$ & $23^{3}(16.4)$ & $10(6.6)$ & $33(11.3)$ \\
\hline Serum selenium $^{1}(\mu \mathrm{g} / \mathrm{L})$ & $61.6 \pm 14.3$ & $60.5 \pm 12.9$ & $61.0 \pm 13.6$ \\
\hline Selenium $<70 \mu \mathrm{g} / \mathrm{L}, n(\%)$ & $99(71.2)$ & $121(79.6)$ & $220(75.6)$ \\
\hline $\operatorname{Serum}_{\operatorname{zinc}}^{2}(\mu \mathrm{g} / \mathrm{L})$ & $467.4(452.2 ; 483.2)$ & $483.5(466.1 ; 501.5)$ & $475.7(464.1 ; 487.7)$ \\
\hline Zinc $<650 \mu \mathrm{g} / \mathrm{L}, n(\%)$ & $130(93.5)$ & $136(89.5)$ & $266(91.4)$ \\
\hline Serum copper ${ }^{1}(\mu \mathrm{g} / \mathrm{L})$ & $1006.7 \pm 143.9^{3}$ & $952.4 \pm 180.9$ & $978.3 \pm 166.2$ \\
\hline Copper $<750 \mu \mathrm{g} / \mathrm{L}, n(\%)$ & $6(4.3)^{4}$ & $19(12.5)$ & $25(8.6)$ \\
\hline Serum magnesium $^{1}(\mathrm{mg} / \mathrm{L})$ & $17.5 \pm 2.0$ & $17.8 \pm 1.7$ & $17.7 \pm 1.8$ \\
\hline Magnesium $<18.0 \mathrm{mg} / \mathrm{L}, n(\%)$ & $91(65.5)^{4}$ & $82(53.9)$ & $173(59.5)$ \\
\hline
\end{tabular}

${ }^{1}$ Mean \pm SD. ${ }^{2}$ Geometric mean $(95 \% \mathrm{CI}) .{ }^{3} p<0.01 .{ }^{4} p<0.05$ compared to girls.

Anemia: $\mathrm{Hb}<115 \mathrm{~g} / \mathrm{L}$; Vitamin A deficiency: serum retinol $<0.70 \mu \mathrm{mol} / \mathrm{L}$.

Table 2. Factors associated with anemia and low serum levels of trace elements among primary school children living in rural Vietnam.

\begin{tabular}{|c|c|c|c|c|}
\hline Dependent variable & Independent variables & OR & $95 \% \mathrm{CI}$ & $p$-value \\
\hline \multirow[t]{5}{*}{ Anemia $^{1}$} & Selenium $<70 \mu \mathrm{g} / \mathrm{L}$ & 1.85 & $1.06-3.24$ & $<0.05$ \\
\hline & Serum retinol $<1.05 \mu \mathrm{mol} / \mathrm{L}$ & 2.05 & $1.25-3.36$ & $<0.01$ \\
\hline & Zinc $<650 \mu \mathrm{g} / \mathrm{L}$ & 0.62 & $0.27-1.41$ & NS \\
\hline & Magnesium <18.0 mg/L & 1.31 & $0.81-2.11$ & NS \\
\hline & Age $(y)$ & 1.59 & $1.16-2.18$ & $<0.01$ \\
\hline \multirow[t]{5}{*}{ Selenium $<70 \mu \mathrm{g} / \mathrm{L}$} & Anemia & 1.85 & $1.06-3.24$ & $<0.05$ \\
\hline & Serum retinol $<1.05 \mu \mathrm{mol} / \mathrm{L}$ & 1.33 & $0.77-2.30$ & NS \\
\hline & Zinc $<650 \mu \mathrm{g} / \mathrm{L}$ & 1.52 & $0.62-3.68$ & NS \\
\hline & Magnesium $<18.0 \mathrm{mg} / \mathrm{L}$ & 1.10 & $0.64-1.89$ & NS \\
\hline & Age $(y)$ & 0.74 & $0.52-1.05$ & NS \\
\hline \multirow[t]{5}{*}{ Zinc $<650 \mu \mathrm{g} / \mathrm{L}$} & Anemia & 0.62 & $0.27-1.41$ & NS \\
\hline & Serum retinol $<1.05 \mu \mathrm{mol} / \mathrm{L}$ & 2.47 & $1.08-5.67$ & $<0.05$ \\
\hline & Selenium $<70 \mu \mathrm{g} / \mathrm{L}$ & 1.52 & $0.62-3.68$ & NS \\
\hline & Magnesium $<18.0 \mathrm{mg} / \mathrm{L}$ & 1.17 & $0.51-2.67$ & NS \\
\hline & Age $(y)$ & 0.35 & $0.20-0.61$ & $<0.001$ \\
\hline \multirow[t]{5}{*}{ Magnesium $<18.0 \mathrm{mg} / \mathrm{L}$} & Anemia & 1.31 & $0.81-2.11$ & NS \\
\hline & Serum retinol $<1.05 \mu \mathrm{mol} / \mathrm{L}$ & 1.11 & $0.68-1.81$ & NS \\
\hline & Selenium $<70 \mu \mathrm{g} / \mathrm{L}$ & 1.10 & $0.64-1.89$ & NS \\
\hline & Zinc $<650 \mu \mathrm{g} / \mathrm{L}$ & 1.17 & $0.51-2.67$ & NS \\
\hline & Age (y) & 1.12 & $0.82-1.54$ & NS \\
\hline
\end{tabular}

${ }^{1} \mathrm{Hb}<115$ g/L. NS: not significant.

The concentrations of serum elements among the schoolchildren are shown in Table 1 . The mean \pm SD, or geometric mean (95\% CI) concentration of selenium, zinc, copper, and magnesium were $61.0 \pm 13.6 \mu \mathrm{g} / \mathrm{L}$, $475.7(464.1 ; 487.7) \mu \mathrm{g} / \mathrm{L}, 978.3 \pm 166.2 \mu \mathrm{g} / \mathrm{L}$, and $17.7 \pm 1.8 \mathrm{mg} / \mathrm{L}$, respectively. The levels of copper in sera of boys were significantly higher $(p<0.01)$ than those in girls. However, there was no significant difference in concentrations of serum selenium, zinc, or mag- nesium between the two genders. The prevalence of low circulating values for selenium, zinc, and magnesium was $75.6,91.4$, and $59.5 \%$, respectively. But only 25 children $(8.6 \%)$ were found with low serum levels of copper. In this study, a combination of anemia and low levels of zinc occurred in $40.1 \%(n=116)$ of the subjects. About $35 \%(n=101)$ had anemia and low selenium status, while $24.8 \%(n=82)$ had anemia and low magnesium levels. 
Binary logistic regression analysis was conducted to examine the factors associated with anemia and low serum levels of micronutrients (Table 2). Low selenium status (OR 1.85, 95\% CI 1.06-3.24, p<0.05) was significantly associated with an increased prevalence of anemia, and vice versa. Another factors associated with anemia were serum retinol $<1.05 \mu \mathrm{mol} / \mathrm{L}$ (OR 2.05, 95\% CI 1.25-3.36, $p<0.01$ ), and age in years (OR $1.59,95 \%$ CI 1.16-2.18, $p<0.01)$. In addition, serum retinol $<1.05 \mu \mathrm{mol} / \mathrm{L}$ (OR 2.47, 95\% CI 1.08-5.67, $p<0.05$ ) and age in years (OR 0.35, 95\% CI 0.20-0.61, $p<0.001$ ) were found to be factors associated with low serum zinc concentration. However, there was no significant factor associated with low levels of magnesium.

\section{DISCUSSION}

The present study demonstrated that anemia is extremely high, occurring in $45.2 \%$ of the study subjects. This indicates that anemia is still an important public health problem among primary school children in Vietnam. These data are consistent with our previous finding that the prevalence of anemia, defined as $\mathrm{Hb}$ concentrations below $110 \mathrm{~g} / \mathrm{L}$, were $28.4 \%$ in preschool children aged less than $5 \mathrm{y}$ in the country (6). Another study in Thailand found the prevalence of anemia as high as 31\% among schoolchildren aged 6-13 y (22). Iron deficiency is a main cause of anemia (19). However, supplementation with iron or iron in combination with other micronutrients may reduce only 40$60 \%$ of the anemia (23-25), and a large proportion of anemia is not responsive to supplementation. In our data it was observed that micronutrient deficiencies often coexist and the interactions between micronutrients are also important. Therefore, anemia may be a consequence of other micronutrient deficiencies.

The results of our study showed an association of low serum levels of selenium with anemia in these children. Lower serum selenium levels have been described in anemic compared with non-anemic adults in Vietnam (7). In addition, low selenium concentrations have been associated with anemia in older adults living in US (8). Selenium is contained in glutathione peroxidase, an enzyme that plays a major role in protection against free radicals and oxidative stress (26). A possible biological mechanism by which selenium deficiency could cause anemia is by upregulation of heme oxygenase-1, which catalyzes the initial step of heme metabolism and reduces heme to biliverdin, carbon monoxide, and free divalent iron. Heme oxygenase-1 has anti-inflammatory properties and it may cause a chronic inflammatory syndrome. In addition, heme oxygenase- 1 releases $\mathrm{Fe}^{2+}$ from the core of the heme molecule, leading to the rapid expression of the iron-sequestering protein ferritin as well as an ATPase pump that actively removes intracellular iron from the cell $(27,28)$.

Another possible biological mechanism by which selenium could contribute to anemia is through modulation of inflammation. Low serum selenium levels were found in adults with anemia of chronic inflammation. Low serum selenium concentrations among disabled older women living in US were predictive of subsequent rises in interleukin-6 (29). Thus, selenium could potentially play a role in the anemia of chronic inflammation through its relationship with the upregulation of interleukin- 6 . In addition, interleukin- 6 has been implicated in the upregulation of hepcidin, the iron regulatory hormone which has a function in the anemia of chronic inflammation is through a central role in regulation of iron metabolism also providing a link between iron metabolism and inflammation and innate immunity $(30,31)$. It has also been shown that selenium deficiency causes anemia among animals and has been associated with a hemolytic anemia (32). Maintenance of an optimal concentration of glutathione peroxidase in erythrocytes was shown to protect hemoglobin against oxidation in erythrocytes in animal studies (33). This suggested that increased oxidative stress could be another mechanism by which selenium deficiency could contribute to anemia (33).

The dietary intake of selenium varies widely worldwide, as selenium levels in plant based foods reflect the concentrations of selenium in the soil where the plants were grown. The selenium concentrations in animal sources of food depend upon the selenium content of the plants used for forage. Risk factors for low serum selenium levels are low intake of animal products. The global distribution of selenium deficiency has not been well characterized and the selenium content of the soil is low and selenium intake is still limited (34).

There has been a remarkable decrease in the prevalence of VAD in Vietnam in recent years. However, the total prevalence of VAD was found to be $11.3 \%$ in the study population. Furthermore, our study showed that $52.6 \%$ of the children had concentrations indicative of marginal vitamin A status (0.70-1.04 $\mu \mathrm{mol} / \mathrm{L})$ and, thus, they are very vulnerable to deficiency. This indicates that VAD is still an important public health problem among the children. In this study, we also found that serum retinol concentrations are positively correlated with $\mathrm{Hb}$ levels. This finding is in agreement with our previous results $(6,7)$ and the results from other studies $(5,35,36)$. VAD appears to impair Hb synthesis (37). This was most clearly demonstrated in several clinical trials where supplementation of vitamin A was responsive to $\mathrm{Hb}$ levels or iron status in Malawian infants (38), Tanzanian school children (39), and Indonesian pregnant women $(3,40)$.

The prevalence of low serum zinc concentration was found in more than $90 \%$ of the adolescent girls. This finding is comparable to studies on school girls from other reports where prevalence ranging from $50.6 \%$ to as high as $58.3 \%$ were reported $(14,35)$. However, this prevalence is very high in comparison to the $20 \%$ prevalence set by the International Zinc Nutrition Consultative Group as an indicator of the need for a national intervention program (21). Low serum zinc levels in the present study could be due to an inadequate zinc intake and poor bio-absorption (2). It is worthy of note that several dietary factors are known to affect zinc absorption as a result of physico-chemical interactions in the 
intestine. Phytate, a component in plants with the highest concentration found in seeds (cereal grains/ legumes/nuts) inhibits zinc absorption (41). This might hold true in the subjects of the present study since the staple foods in rural areas of Vietnam are cereal based (2). Like zinc and selenium, the magnesium level was also very low among the children. Therefore the prevalence of magnesium deficiency was very high in the subjects. It appears that more work is required to define acceptable requirements for magnesium intakes, the prevalence of deficiency, and the public health significance.

The dietary intake has not usually been considered as a positive cause of anemia, whereas the consumption of meat products had a positive effect on serum ferritin levels in preschool children (42). However, the daily iron intake was $7.5 \pm 4.0 \mathrm{mg}$ which corresponds to $46 \%$ of the recommended nutrient intake $(16.2 \mathrm{mg} / \mathrm{d})$ in primary school children from northern Vietnam (43). Therefore, our future studies should target the issue from various angles to fully understand the causes of anemia and micronutrient status among children and other populations in Vietnam.

In conclusion, low selenium status is associated with anemia among schoolchildren in Vietnam. In addition, anemia and micronutrient deficiencies are important public health problems among the children. Given the present findings it is urgent that effective interventions and programs be developed to improve and correct the nutritional situation regarding these trace elements uncovered in the present survey.

\section{Acknowledgments}

We are grateful to all the children and their families who participated in the study. The fieldwork staff and technicians of National Institute of Nutrition Vietnam are thanked for their help during data collection. Financial support was obtained from The University of Tokushima, Japan and National Institute of Nutrition Vietnam.

\section{REFERENCES}

1) ACC/SCN. 2000. Fourth Report on the World Nutrition Situation. WHO, Geneva.

2) Khoi HH, Khan NC, Mai LB, Tuyen LD. 2003. General Nutrition Survey 2000. Medical Publishing House, Hanoi.

3) Suharno D, Muhilal, Karyadi D, West CE, Hautvast JGAJ, West CE. 1993. Supplementation with vitamin A and iron for nutritional anemia in pregnant women in West Java, Indonesia. Lancet 342: 1325-1328.

4) Lozoff B, De Andraca I, Castillo M, Smith JB, Walter T, Pino P. 2003. Behavioral and developmental effects of preventing iron-deficiency anemia in healthy full-term infants. Pediatrics 112: 846-854.

5) Semba RD, Bloem MW. 2002. The anemia of vitamin A deficiency: epidemiology and pathogenesis. Eur J Clin Nutr 56: 271-281.

6) Khan NC, Ninh NX, Van Nhien N, Khoi HH, West CE, Hautvast JG. 2007. Sub clinical vitamin A deficiency and anemia among Vietnamese children less than five years of age. Asia Pac J Clin Nutr 16: 152-157.

7) Van Nhien N, Khan NC, Yabutani T, Ninh NX, Huong BTM, Do TT, Motonaka J, Ota F. 2006. Serum levels of trace elements and iron deficiency anemia in adult Vietnamese. Biol Trace Elem Res 111: 1-9.

8) Semba RD, Ferrucci L, Cappola AR, Ricks MO, Ray AL, Xue QL, Guralnik JM, Fried LP. 2006. Low serum selenium is associated with anemia among older women living in the community: the women's health and aging studies I and II. Biol Trace Elem Res 112: 97-107.

9) WHO. 1996. Trace Elements in Human Nutrition and Health. WHO, Geneva.

10) Failla ML. 2003. Trace elements and host defense: recent advances and continuing challenges. J Nutr 133: S1443-1447.

11) Gamble MV, Palafox NA, Dancheck B, Ricks MO, Briand K, Semba RD. 2004. Relationship of vitamin A deficiency, iron deficiency, and inflammation to anemia among preschool children in the Republic of the Marshall Islands. Eur J Clin Nutr 58: 1396-1401.

12) Krittaphol W, Bailey KB, Pongcharoen T, Winichagoon P, Thomson C, Gibson RS. 2006. Primary school children from northeast Thailand are not at risk of selenium deficiency. Asia Pac J Clin Nutr 5: 474-481.

13) Cinaz P, Karakasu DS, Camurdan MO, Bideci A, Ayvali ED, Yucel C. 2004. Goiter prevalence, serum selenium, and urine iodine status in a previously iodine-deficient area in Turkey. Biol Trace Elem Res 100: 185-193.

14) Hettiarachchi M, Liyanage $C$, Wickremasinghe R, Hilmers DC, Abrahams SA. 2006. Prevalence and severity of micronutrient deficiency: a cross-sectional study among adolescents in Sri Lanka. Asia Pac J Clin Nutr 15: 5663.

15) Levy PS, Lemeshow S. 1999. Sampling of Populations. Methods and Applications, 3rd ed. John Wiley \& Sons Inc., New York.

16) National Center for Health Statistics. 1977. NCHS Growth Curves for Children, Birth-18 Years. US Department of Health, Education and Welfare, Washington DC.

17) IVACG. 1982. Biochemical Methodology for Assessment of Vitamin A Status. The Nutrition Foundation, Washington DC.

18) Hasegawa T, Inagaki K, Haraguchi H. 2001. Multielement correlation analysis of major to trace elements in human blood serum for medical diagnosis as studied by ICP-AES and ICP-MS. Anal Sci 17: i979-982.

19) WHO. 2001. Iron Deficiency Anemia: Assessment, Prevention, and Control. WHO, Geneva.

20) Sauberlich HE. 1999. Laboratory Tests for the Assessment of Nutritional Status, 2nd ed. CRC Press, Boca Raton.

21) Hotz C, Brown K. 2004. Assessment of the risk of zinc deficiency in populations and options for its control. Food Nutr Bull 25: S99-S203.

22) Thurlow RA, Winichagoon P, Green T, Wasantwisut E, Pongcharoen T, Bailey KB, Gibson RS. 2005. Only a small proportion of anemia in northeast Thai schoolchildren is associated with iron deficiency. Am J Clin Nutr 82: 380-387.

23) Allen LH, Rosado JL, Casterline JE, López P, Muñoz E, Garcia OP, Martinez H. 2000. Lack of hemoglobin response to iron supplementation in anemic Mexican preschoolers with multiple micronutrient deficiencies. Am J Clin Nutr 71: 1485-1494. 
24) Hop LT, Berger J. 2005. Multiple micronutrient supplementation improves anemia, micronutrient nutrient status, and growth of Vietnamese infants: double-blind, randomized, placebo-controlled trial. J Nutr 135: S660-665.

25) Untoro J, Karyadi E, Wibowo L, Erhardt MW, Gross R. 2005. Multiple micronutrient supplements improve micronutrient status and anemia but not growth and morbidity of Indonesian infants: a randomized, doubleblind, placebo-controlled trial. J Nutr 135: S639-645.

26) Kaur P, Bansal MP. 2004. Effect of experimental oxidative stress on steroidogenesis and DNA damage in mouse testis. J Biomed Sci 11: 391-397.

27) Mostert V, Nakayama A, Austin LM, Levander XA, Ferris CD, Hill KE, Burk RF. 2007. Serum iron increases with acute induction of hepatic heme oxygenase-1 in mice. Drug Metab Rev 39: 619-626.

28) Tron K, Novosyadlyy R, Dudas J, Samoylenko A, Kietzmann T, Ramadori G. 2005. Upregulation of heme oxygenase-1 gene by turpentine oil-induced localized inflammation: involvement of interleukin-6. Lab Invest 85: $376-387$.

29) Walston J, Xue Q, Semba RD, Ferrucci L, Cappola AR, Ricks M, Guralnik J, Fried LP. 2006. Serum antioxidants, inflammation, and total mortality in older women. Am J Epidemiol 163: 18-26.

30) Atanasiu V, Manolescu B, Stoian I. 2007. Hepcidincentral regulator of iron metabolism. Eur J Haematol 78: $1-10$.

31) Raj DS. 2008. Role of interleukin-6 in the anemia of chronic disease. Semin Arthritis Rheum (in press).

32) Nasr MR, Ali S, Shaker M, Elgabry E. 2002. Antioxidant micronutrients in children with thalassaemia in Egypt. East Mediterr Health J 8: 490-495.

33) Chow CK, Chen CJ. 1980. Dietary selenium and agerelated susceptibility of rat erythrocytes to oxidative damage. J Nutr 110: 2460-2466.

34) Semba RD. 2007. Selenium. In: Nutritional Anemia (Zimmermann MB, ed), p 189-197. Sight and Life Press, Basel.
35) Thurlow RA, Winichagoon P, Pongcharoen T, Gowachirapant S, Boonpraderm A, Manger MS, Bailey KB, Wasantwisut E, Gibson RS. 2006. Risk of zinc, iodine and other micronutrient deficiencies among school children in North East Thailand. Eur J Clin Nutr 60: 623-632.

36) Palafox NA, Gamble MV, Dancheck B, Ricks MO, Briand K, Semba RD. 2003. Vitamin A deficiency, iron deficiency, and anemia among preschool children in the Republic of the Marshall Islands. Nutrition 19: 405408.

37) Hodges RE, Sauberlich HE, Mohanram M. 1978. Hematopoietic studies in vitamin A deficiency. Am J Clin Nutr 31: 876-885.

38) Kumwenda N, Miotti PG, Taha TE, Broadhead R, Biggar RJ, Jackson JB, Melikian G, Semba RD. 2002. Antenatal vitamin A supplementation increases birth weight and decreases anemia among infants born to human immunodeficiency virus-infected women in Malawi. Clin Infect Dis 35: 618-624.

39) Mwanri L, Worsley A, Ryan P, Masika J. 2000. Supplemental vitamin A improves anemia and growth in anemic school children in Tanzania. J Nutr 130: 26912696.

40) Muslimatun S, Schmidt MK, Schultink W, Hautvast JG, Karyadi D. 2001. Weekly supplementation with iron and vitamin A during pregnancy increases hemoglobin concentration but decreases serum ferritin concentration in Indonesian pregnant women. J Nutr 131: 8590.

41) Gibson RS. 1994. Zinc nutrition in developing countries. Nutr Res Rev 7: 151-173.

42) Ohlund I, Lind T, Hörnell A, Hernell O. 2008. Predictors of iron status in well-nourished 4-y-old children. Am J Clin Nutr 87: 839-845.

43) Le HT, Brouwer ID, Verhoef H, Nguyen KC, Kok FJ. 2007. Anemia and intestinal parasite infection in school children in rural Vietnam. Asia Pac J Clin Nutr 16: $716-723$. 